\title{
A subchronic toxicity test of Flacourtia rukam stem bark extract on the albino rat Rattus noverticus (Wistar strain)
}

\author{
Muharni Muharni $^{1 *}$, Fitrya Fitrya ${ }^{2}$, Oki Saputra ${ }^{2}$, Heni Yohandini ${ }^{1}$, Julinar Julinar ${ }^{1}$ \\ ${ }^{1}$ Department of Chemistry, Faculty of Mathematics and Natural Sciences, University of Sriwijaya, Jl. Raya Palembang-Prabumulih Km 32, Indralaya, Ogan Ilir, \\ South Sumatra, Indonesia. \\ ${ }^{2}$ Department of Pharmacy, Faculty of Mathematics and Natural Sciences, University of Sriwijaya, Jl. Raya Palembang-Prabumulih Km 32, Indralaya, Ogan Ilir, \\ South Sumatra, Indonesia.
}

\section{ARTICLE INFO}

Article history:

Received on: October 22, 2020

Accepted on: January 02, 2021

Available online: May 10, 2021

\section{Key words:}

Flacourtia rukam,

Hypertension,

Subchronic toxicity,

Albino rats.

\section{ABSTRACT}

Flacourtia rukam is used as a traditional Indonesian treatment for hypertension. The toxicity of this natural ingredient needs to be tested, especially for long-term usage. Here, we report subchronic toxicity testing of an ethanol extract from the stem bark of F. rukam on the albino rat, Rattus noverticus (Wistar strain). The experiment used 30 male and 30 female albino rats, each divided into 5 groups, that is, a control group and 4 treatment groups (doses of 200, 400, 600 , and $800 \mathrm{mg} / \mathrm{kg}$ body weight [BW]). The experiment ran for 90 days. The toxicity effect was based on several parameters: Physical symptoms, weight, blood hematology (hemoglobin, erythrocytes, leukocytes, and hematocrit), blood biochemistry (serum glutamic oxaloacetic transaminase, serum glutamic pyruvic transaminase, and creatinine), and relative organ weight. The results showed no significant difference between control and treatment groups up to a $600 \mathrm{mg} / \mathrm{kg}$ dose, but significant difference was observed at a $800 \mathrm{mg} / \mathrm{kg}$ dose. The difference, however, was still in the acceptable limits. Normal parameters resulted from biochemical examination, blood hematology, and BW, overall showed leading that F. rukam stem bark extract is not significantly toxic in the test animals.

\section{INTRODUCTION}

Indonesians have historically used medicinal plants to overcome health problems, using knowledge passed on from previous generations. Herbal medicines are often promoted as safe treatments, however, sometimes toxicity testing has proved otherwise [1,2]. A treatment should pass a toxicity test before being accepted as a standard herbal medicine. One plant which is widely used as an herbal medicine is Flacourtia rukam, or rukam. F. rukam is known by several different names throughout South Asia such as: Sweet rukam and elephant rukan in Malaysia; amaiit (Tagalog), aganas (Bisaya), and kalominga (Igorot) in Philippines and rukem (Java) and klang tatah kutang (Borneo) in Indonesia. Rukam thrives in the wild and is cultivated in Malaysia, but it is rarely found in the Moluccas and Papua New Guinea. Indonesians, particularly residents of Musi Banyuasin, South Sumatera, make a stew from F. rukam stem bark for use as an antihypertension and anticholesterol medicine [3].

Five compounds monogalactosyl diacylglycerol, $\beta$-sitosterol-3 $\beta$ glucopyranocide-6 $\beta$-fatty acid ester, $\beta$-sitosterol, triacylglycerol, and

*Corresponding Author

Muharni Muharni,

Department of Chemistry, Faculty of Mathematics and Natural Sciences,

University of Sriwijaya, Jl. Raya Palembang-Prabumulih Km 32, Indralaya,

Ogan Ilir, South Sumatra, Indonesia.

E-mail:muharnimyd@yahoo.co.id chrlofile A extracted from F. rukam fruit [4]. The twigs also contain friedelin and stigmastan 3,6-dion. We have also previously found friedelin and two other compounds (poliothrysoside and $\beta$-sitosterolD-glucoside) in F. rukam stem bark [5], and apigenin compound is found in the leaves. We also reported that a F. rukam stem bark extract showed antihypertension activity, determined by ACE method, with $\mathrm{IC}_{50}$ $119.82 \mathrm{mg} / \mathrm{L}$ and anticholesterol activity with $\mathrm{IC}_{50} 157.88 \mathrm{mg} / \mathrm{L}$. In in vivo testing, the effective dose to lower cholesterol $\left(E_{50}\right)$ was $373 \mathrm{mg} / \mathrm{kg}$. The standardized extract fulfilled all test parameters, suggesting that this extract has the potential to lower hypertension symptoms [6].

The stem bark of F. rukam has been used as a traditional medicine for antihypertension and anticholesterol. Long-term usage of such medicinal herbs might have a toxic effect on vital organs. However, there are no detailed studies on the potential toxicity of $F$. rukam stem bark extracts. Here, we report on the toxicity of an F. rukam stem bark extract on male and female albino rats which received doses of 200, 400,600 , and $800 \mathrm{mg} / \mathrm{kg}$ body weight (BW). Toxicity was evaluated by blood hematology and biochemistry, and at autopsy by weighing vital organs (liver, heart, and kidney).

\section{MATERIALS AND METHODS}

\subsection{Chemicals and Equipment}

Materials used in this study: The stem bark of F. rukam, filter paper, rat feed, distilled water $\left(\right.$ Brataco $\left.^{\circledR}\right)$, ethanol $70 \%\left(\right.$ Brataco $\left.^{\circledR}\right), \mathrm{Na}$ 
CMC (Brataco ${ }^{\circledR}$ ), serum glutamic oxaloacetic transaminase (SGOT), and serum pyruvic oxalic transaminase (serum glutamic pyruvic transaminase [SGPT]) reagents $\left(\mathrm{DIALAB}^{\circledR}\right)$, and creatinine reagent (Reiged Diagnostic ${ }^{\circledR}$ ). Tools used in this study: Rotary evaporator $\left(\right.$ Yamato $\left.^{\circledR}\right)$, EDTA and non-EDTA (Vaculab ${ }^{\circledR}$ ) vacutainer tubes, surgical equipment (Gold Cross ${ }^{\circledR}$ ), and Clinical Chemistry Analyzer (DIALAB, DTN-410-K ${ }^{\circledR}$ ).

\subsection{Sample Identification and Preparation}

F. rukam stem bark ( $3 \mathrm{~kg}$ ) was collected from Ngulak I village, Musi Banyuasin district in South Sumatera Province, Indonesia. The sample was identified as F. rukam at the Biology Department, Faculty of Mathematics and Natural Sciences, Sriwijaya University, by Dr. Laila Hanum (specimen number VIC 2702). Before extraction, the sample was cut into small pieces and dried at room temperature under indirect sunlight until its weight was constant. The dried stem bark sample was then ground into a powder $(1.45 \mathrm{~kg})$.

\subsection{Experimental Animals}

Male and female albino rats (Wistar strain, aged 2-3 months, weighing 150-200 g, 30 males, and 30 females) were obtained from the Faculty of Public Health, University of Sriwijaya, Palembang, Indonesia. The animals were housed in the Laboratory Pharmacology, Department of Pharmacy, Faculty of Mathematics and Natural Sciences, University of Sriwijaya. The experimental protocol was approved by the Ethics Commission of Sriwijaya University (No. 072/keprsmhfkunsri/2020) and carried out in accordance with recent guidance for animal nurture in the laboratory.

\subsection{Extraction}

F. rukam stem bark powder $(1.45 \mathrm{~kg})$ was macerated using ethanol $70 \%(\mathrm{v} / \mathrm{v})$ for $3 \times 24 \mathrm{~h}$ with 3 repetitions. The solvent was evaporated using a rotary evaporator $\left(70^{\circ} \mathrm{C}\right)$. The concentrated product was collected and weighed to calculate the yield percent.

\subsection{Subchronic Toxicity Test}

Animals were acclimatized for 7 days by administering standard feed and drink. The 30 male rats were divided into 5 groups of 6 animals, so too were the female rats. Group I was the control and received $0.5 \%$ $\mathrm{Na} \mathrm{CMC}$ in place of the extract. Groups II-V received the extract at doses of 200, 400,600, and $800 \mathrm{mg} / \mathrm{kg} \mathrm{BW}$ daily for 3 months, respectively. During the experiment, animals had access to feed and drink daily, according to standard needed [7].

\subsection{Determination of Blood Hematology and Biochemistry}

Subchronic toxicity was determined by observing clinical motoric activity symptoms and animal feces. Animals were weighed once a week. At days 31 and 91, test animals had blood samples taken for determination of hematology (hemoglobin, leukocytes, erythrocytes, and hematocrit) and blood biochemistry (SGOT, SGPT, and creatinine) using the analysis conducted by clinical chemistry analysis. Blood (3-4 $\mathrm{ml})$ was collected through retro-orbital sampling into tubes without coagulant. Blood samples were centrifuged (10 min, 5000 $\mathrm{rpm})$ to separate the serum from erythrocytes. The serum was used in blood biochemistry analysis [8]. At the end of the experiment (day 91), the weights of vital organs were measured.

\subsection{Determination of Relative Organ Weight (ROW)}

Animals were euthanized on day 91 by intraperitoneal injection of $15 \mathrm{mg} / 100 \mathrm{~g}$ BW of sodium pentobarbital. The liver, heart, and kidneys were collected by surgical procedure and the ROWs determined [9]. The examination of the ROW index was conducted by weighing the heart, liver, and kidneys. The relative weight of organs was calculated by dividing the organ weight by the BW and multiplying by 100 to produce the relative organ index.

\subsection{Data Analysis}

The paired $t$-test was used to determine if there was significant difference in animal weight before and after treatment with the extract. The independent T-test was used to compare organ weight, SGOT, SGPT, creatinine, hemoglobin, erythrocytes, leukocytes, and hematocrit in animals subjected to the different treatments.

\section{RESULTS AND DISCUSSION}

\subsection{Result}

The main goal of this work was to evaluate the safety of an F. rukam stem bark extract in male and female albino rats (Wister strain) by analyzing blood hematology and biochemistry data. The subchronic toxicity effect was also assessed by analyzing ROWs.

\subsubsection{Plant extraction}

Dried F. rukam stem bark was ground into a powder $(1.45 \mathrm{~kg}$ dried powder) then macerated with ethanol and concentrated by rotary evaporation. The end product weighed $72.5 \mathrm{~g}$. The percentage yield (w/w) of the ethanol extract was $5.0 \%$.

\subsubsection{Observation of toxic symptoms in test animals}

Animals were observed for physical symptoms and we analyzed the motoric activity, feces, and BW for signs of toxicity. The results are displayed in Tables 1 and 2 .

\subsubsection{Blood biochemistry analysis}

The toxicity of the extract was assessed by evaluating SGOT, SGPT, and creatinine levels. SGOT and SGPT are often associated with liver damage. Average values of SGOT, SGPT, and creatinine obtained for the male and female albino rats are displayed in Table 3.

Table 1: The motoric activity and observation feces to tested rats after extract injection.

\begin{tabular}{|c|c|c|c|c|c|}
\hline \multirow[t]{2}{*}{ Group } & \multirow[t]{2}{*}{ Treatment } & \multicolumn{2}{|c|}{ Total of rats } & \multirow[t]{2}{*}{ Motoric activity } & \multirow[t]{2}{*}{ Faces } \\
\hline & & Male & Female & & \\
\hline I & Normal & 6 & 6 & Normal & Normal \\
\hline II & Extract dose $200 \mathrm{mg} / \mathrm{kg} \mathrm{BW}$ & 6 & 6 & Normal & Normal \\
\hline III & Extract dose $400 \mathrm{mg} / \mathrm{kg} \mathrm{BW}$ & 6 & 6 & Normal & Normal \\
\hline IV & Extract dose $600 \mathrm{mg} / \mathrm{kg} \mathrm{BW}$ & 6 & 6 & Normal & Normal \\
\hline $\mathrm{V}$ & Extract dose $800 \mathrm{mg} / \mathrm{kg} \mathrm{BW}$ & 6 & 6 & Normal & Normal \\
\hline
\end{tabular}

BW: Body weight 


\subsubsection{Hematology parameter evaluation}

The hematology parameters analyzed were hemoglobin, erythrocytes, leukocytes, and hematocrit. The hematology analysis was necessary to diagnose and assess the effect of the extract on blood and bloodforming tissue [10]. Average levels of blood hematology for male and female albino rats are shown in Table 4.

\subsubsection{Relative weight of vital organs and macroscopic parameter} The relative weight of a vital organ is defined as the ratio of absolute organ weight to BW [9]. The results are shown in Tables 5 and 6.

\section{DISCUSSION}

Subchronic toxicity is adverse effects occurring after the repeated or continuous administration of a test sample for a part of the animal's lifespan [11]. In this study subchronic toxicity first, we analyzed the motoric activity and BW of albino rats after treatment effects. Based on data Table 1, there was no observable decrease in motoric activity of animals that received the extract, nor change in the physical appearance of feces, nor death. There was no difference in the motoric movement of the treated groups compared the control group. The stools from the treated mice had normal shape and texture. Therefore, it can be concluded that the extract does not affect

Table 2: BW increases of tested rats every weak.

\begin{tabular}{llcc} 
Group & Treatment & \multicolumn{2}{c}{$\begin{array}{c}\text { Increase of BW }(\mathrm{g}) \\
\text { Average } \pm \text { SD }\end{array}$} \\
\cline { 3 - 4 } & & Male & Female \\
I & Normal & $6.73 \pm 0.75$ & $8.67 \pm 2.62$ \\
II & Extract dose $200 \mathrm{mg} / \mathrm{kg} \mathrm{BW}$ & $9.19 \pm 0.18$ & $7.65 \pm 0.51$ \\
III & Extract dose $400 \mathrm{mg} / \mathrm{kg} \mathrm{BW}$ & $6.28 \pm 0.19$ & $7.59 \pm 1.67$ \\
IV & Extract dose $600 \mathrm{mg} / \mathrm{kg} \mathrm{BW}$ & $8.15 \pm 0.60$ & $8.55 \pm 2.13$ \\
V & Extract dose $800 \mathrm{mg} / \mathrm{kg} \mathrm{BW}$ & $8.23 \pm 1.63$ & $9.03 \pm 1.29$ \\
\hline
\end{tabular}

BW: Body weight motoric activity [Table 1]. Change in BW is considered to be a valid indicator of subchronic toxicity [12]. A drastic increase or decrease of BW correlates with the health condition. BW was measured weekly over the 12 weeks of the experiment; weight increases were detected. Normally, a rat will gain weight as it gets older, such as over the 3 months of the experiment [13]. Table 2 shows that the weight of the male rats increased by $6.28-9.19 \mathrm{~g} / \mathrm{week}$ and that of the female rats increased by $7.59-9.03 \mathrm{~g} /$ week. Statistic calculation $(P>0.05)$ confirmed that the extract had no significant effect on weight; the weights were still within normal range. Normal BW of 3-4-month-old Wistar rats is 195-269 g. We performed a T-paired analysis of the weight data to assess the weight differences before and after receiving the extract. $P$ value was $P<0.05$, indicating a significant difference. F. rukam stem bark extract affected the albino rat $\mathrm{BW}$.

\subsection{Blood biochemistry analysis}

The normal ranges for SGOT, SGPT, and creatinine values for Wistar rats aged $2-4$ months are $74-143 \mathrm{IU} / \mathrm{L}, 63-175 \mathrm{IU} / \mathrm{L}$, and $0.2-0.6 \mathrm{mg} /$ $\mathrm{dL}$, respectively [14]. Analysis of SGOT and SGPT values for both the control group and treatment groups (doses 200, 400, 600 and $800 \mathrm{mg}$ / $\mathrm{kg} \mathrm{BW}$ ) was carried out using the T-independent test. The test result showed no significant difference between SGOT and SGPT values of control and treatment groups $(P>0.05)$. F. rukam stem bark extract had no effect on SGOT and SGPT of the treatment groups, although a slight difference $(P<0.05)$ was detected with the $800 \mathrm{mg} / \mathrm{kg} \mathrm{BW}$ dose. However, it was still in the range of normal average values. Statistical analysis of creatinine levels showed a significant difference $(P<0.05)$ between the control and the $800 \mathrm{mg} / \mathrm{kg}$ treatment group [Table 3]. The effect of $F$. rukam stem bark extract on creatinine was, hence, confirmed. Even though the creatinine level was relatively high, it was still in the normal range. This increase correlates with high muscle activity, or it can also be due to disturbance of kidney secretions. Overall, creatinine is in stable amount and not affected by the diet protein [15].

Table 3: The SGPT, SGOT, and creatinine levels for male and female rats.

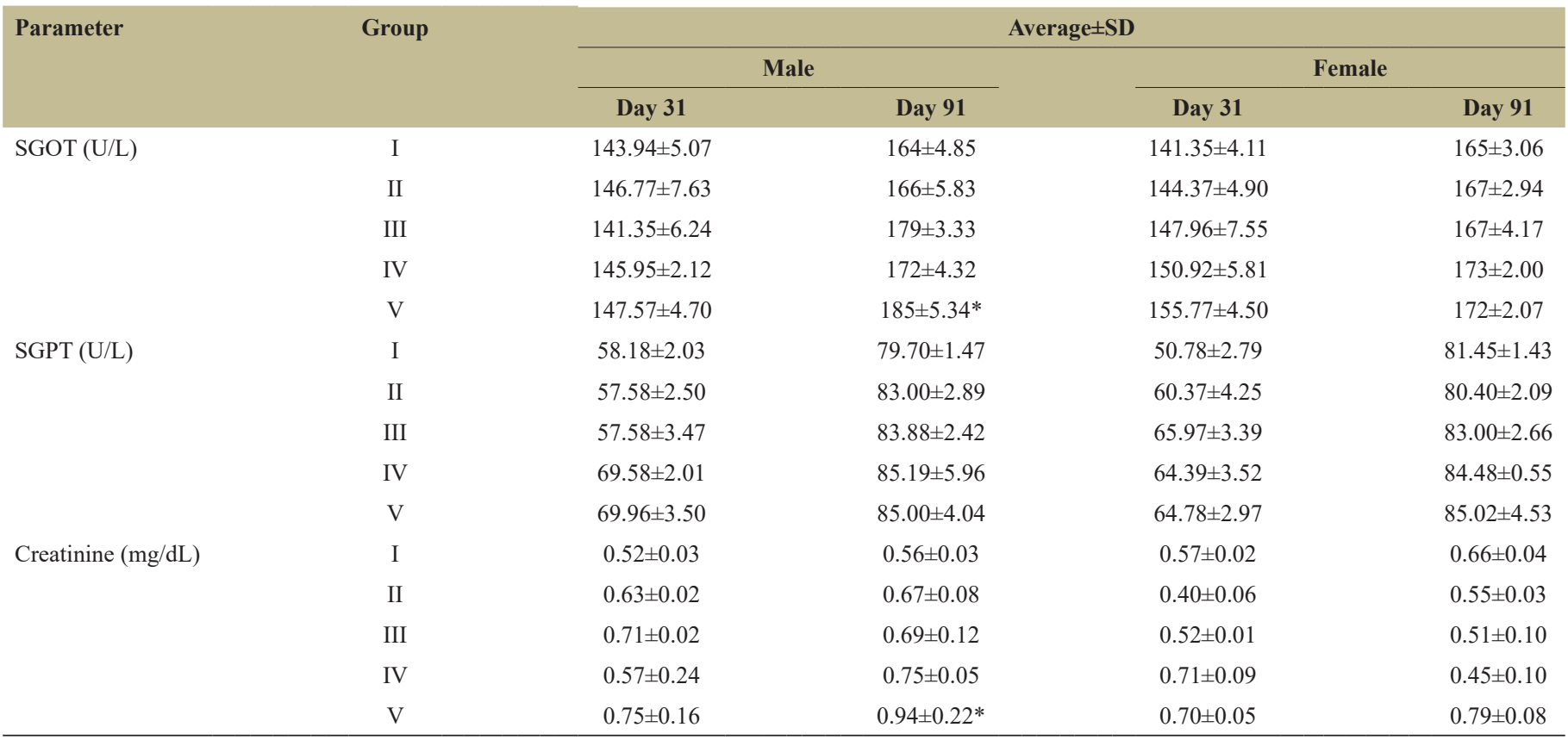

*Significantly different from control group, SGOT: Serum glutamic oxaloacetic transaminase, SGPT: Serum glutamic pyruvic transaminase 
Table 4: Average level of hemoglobin, erythrocytes, leukocyte, and hematocrit of animal.

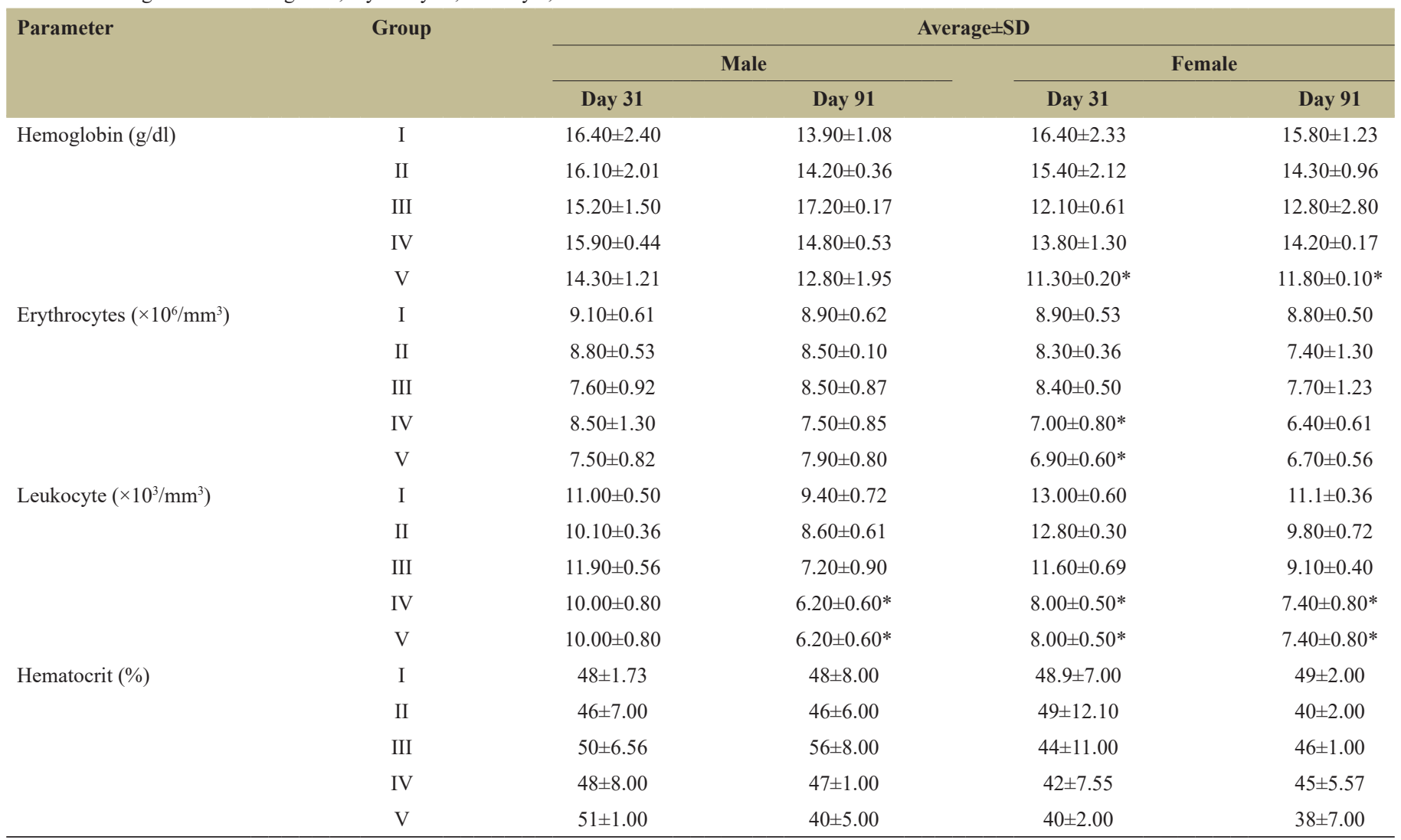

*Significantly different from control group

Table 5: Relative organ weight of tested and control rats.

\begin{tabular}{lcccc}
\multirow{2}{*}{ Gender } & Group & \multicolumn{2}{c}{ ROW of organ (Average \pm SD) } \\
\cline { 3 - 5 } Male & I & $0.45 \pm 0.03$ & $4.07 \pm 0.30$ & $0.86 \pm 0.11$ \\
& II & $0.46 \pm 0.02$ & $4.08 \pm 0.23$ & $0.83 \pm 0.26$ \\
& III & $0.45 \pm 0.02$ & $3.57 \pm 0.25$ & $0.80 \pm 0.14$ \\
& IV & $0.47 \pm 0.04$ & $3.64 \pm 0.32$ & $0.93 \pm 0.18$ \\
& V & $0.85 \pm 0.09^{*}$ & $3.50 \pm 0.56$ & $0.88 \pm 0.21$ \\
& I & $0.47 \pm 0.08$ & $3.93 \pm 0.34$ & $0.80 \pm 0.09$ \\
& II & $0.46 \pm 0.21$ & $3.59 \pm 0.41$ & $0.76 \pm 0.16$ \\
& III & $0.45 \pm 0.07$ & $3.30 \pm 0.38$ & $0.81 \pm 0.17$ \\
& IV & $0.46 \pm 0.16$ & $3.42 \pm 0.17$ & $0.73 \pm 0.07$ \\
& V & $0.65 \pm 0.28^{*}$ & $3.12 \pm 0.33$ & $0.89 \pm 0.16$ \\
\hline
\end{tabular}

*Significantly different from control group

\subsection{Hematology parameter evaluation}

The normal hemoglobin level of albino rats is $8.00-16 \mathrm{~g} / \mathrm{dl}$ [14]. On day 31 and day 91 , there was no significant difference between hemoglobin levels of control and treatment groups $(P>0.05)$. The extract did not affect the hemoglobin $(\mathrm{Hb})$ levels of any animals, except the male control group. At $800 \mathrm{mg} / \mathrm{kg} \mathrm{BW}$ treatment dose, this control animal shows significant difference $(P<0.05)$ although still in normal range of $\mathrm{Hb}$ level [Table 4]. The $\mathrm{Hb}$ level indicates whether the animal suffers from anemia [16]. Low $\mathrm{Hb}$ levels may also be caused by cirrhosis, hyperthyroidism, or bleeding. Low $\mathrm{Hb}$ levels are always followed by a decrease in hematocrit and erythrocytes. The normal level of erythrocytes in rats is $7.2-9.6 \times 10^{6} / \mathrm{mm}^{3}$ blood [14]. Analysis showed a significant difference in erythrocyte levels between female rats of the control group and of the treatment groups receiving doses of 600 and $800 \mathrm{mg} / \mathrm{kg} \mathrm{BW}(P<0.05)$. As for doses of 200 and $400 \mathrm{mg} / \mathrm{kg}$, there was no significant difference compared to the control group $(P>0.05)$. Erythrocytes tended to decease but were still in the acceptable range. The reason for this is the hemolysis of old erythrocytes within the liver and lymph while new production of erythrocytes is still incomplete which causes lower erythrocyte levels [17]. The normal leukocyte level for rats is $1.96-8.25 \times 10^{3} / \mathrm{mm}^{3}$ [14]. Statistic calculation confirmed that the leukocyte levels of both male and female rats in the control and treatment groups (600 and $800 \mathrm{mg} / \mathrm{kg} \mathrm{BW}$ ) differed significantly $(P<0.05)$. F. rukam stem bark extract might have affected the levels of leukocytes of animals at the 600 and $800 \mathrm{mg} / \mathrm{kg} \mathrm{BW}$ doses. At 200 and $400 \mathrm{mg} / \mathrm{kg} \mathrm{BW}$ doses, however, no significant difference was found $(P$ $>0.05$ ). A decrease in leukocytes indicates disturbance of bone marrow. The animal aging during an experiment can cause a decrease in the ability to produce leukocytes compared to younger animals [18]. The immune system provides better leukocyte production at a younger age.

The normal hematocrit level is 39-53\% [19]. Blood analysis at days 31 and 91 [Table 4] showed no significant difference between control and treatment groups $(P>0.05)$. The extract had no effect on the hematocrit levels in any groups. All animals maintained normal hematocrit levels. Hematocrit can be used as an anemia indicator when the level decreases; a $30 \%$ decline is associated with mild to severe anemia. It is also an indicator for hemolytic reaction, leukemia, cirrhosis, blood loss, and hyperthyroidism.

\subsection{Relative vital organ weight and macroscopic parameter}

In this study also carried out a BW evaluation on vital organs heart, kidney, and liver after treatment [Table 5]. Statistical analysis of the 

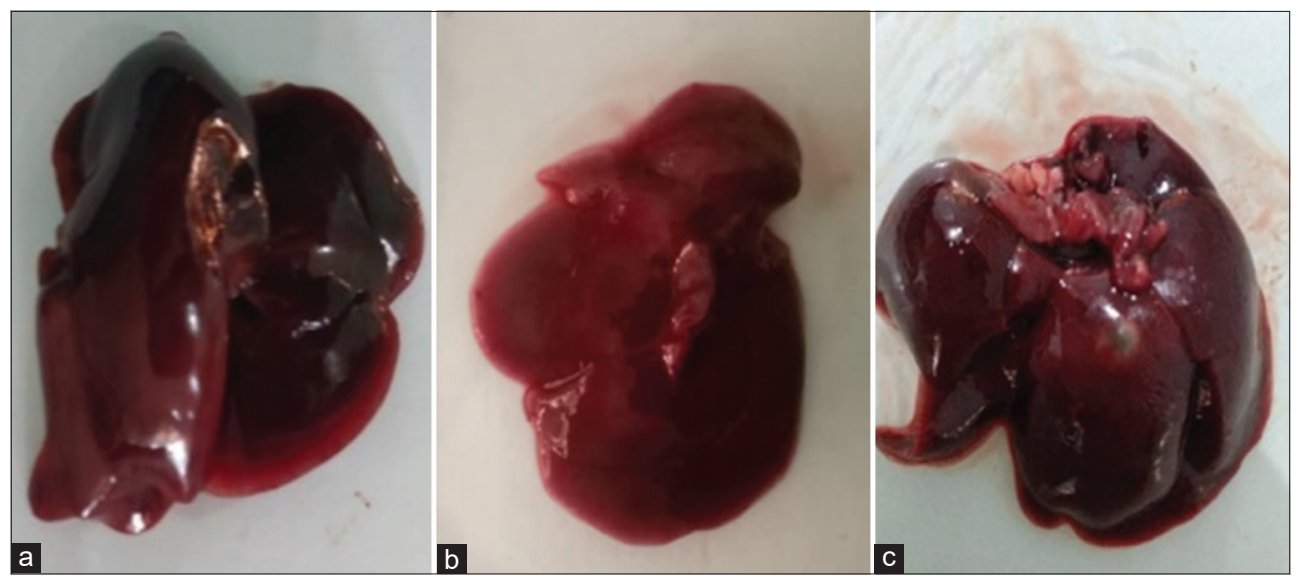

Figure 1: The liver organs of male rat (a), female rat (b) dosage $800 \mathrm{mg} / \mathrm{kg} \mathrm{BW}$, and control (c).

Table 6: Macroscopic parameter of male and female rats' organs.

\begin{tabular}{|c|c|c|c|c|c|c|c|}
\hline \multirow[t]{3}{*}{ Parameter } & \multirow[t]{3}{*}{ Group } & \multicolumn{6}{|c|}{ Organ } \\
\hline & & \multicolumn{2}{|c|}{ Heart } & \multicolumn{2}{|c|}{ Liver } & \multicolumn{2}{|c|}{ Kidney } \\
\hline & & Male & Female & Male & Female & Male & Female \\
\hline & II & Normal & Normal & Normal & Normal & Normal & Normal \\
\hline & III & Normal & Normal & Normal & Normal & Normal & Normal \\
\hline \multirow[t]{4}{*}{ Colour } & I & Maroon & Maroon & Maroon & Maroon & Maroon & Maroon \\
\hline & II & Maroon & Maroon & Maroon & Maroon & Maroon & Maroon \\
\hline & III & Maroon & Maroon & Maroon & Maroon & Maroon & Maroon \\
\hline & IV & Maroon & Maroon & Maroon & Maroon & Maroon & Maroon \\
\hline
\end{tabular}

relative weights of the heart, liver, and kidneys showed a homogeneous pattern and no significant differences between the control and treatment groups, but the heart relative weights show a significant difference between the control and the $800 \mathrm{mg} / \mathrm{kg}$ dose group $(P<0.05)$. Overall, this study showed that there were no significant differences in observed parameters between treated and control rats during extract administration. Heart, kidney, and liver weights tended to increase with dosage. Increases in BW were recorded, but there was no linear correlation with organ weight. Animal weight is affected by visceral fat formed around organs as well as subcutaneous fat inside the body [20]. This study provides important information of the use of F. rukam as traditional medicine, especially in South Sumatra, Indonesia.

In this study also to the macroscopic evaluation of vital organs, liver, heart, and kidney. The aim evaluation correlates toxic properties with changes in treated rats' organ structure, including color and organ condition [Table 6]. Table 7 showed no significantly different and specific change at the liver, heart, and kidney organ on treated groups compared to the control group. There were no inflammation or fattening on the liver; the color and physical appearance were standard [Figure 1]. Overall, this research showed no significant differences in observed parameters between treated and control rats during extract administration. According to data gathered, that is, weigh, blood biochemistry, hematology, and macroscopic observation, it can be concluded that extract treatment provides no toxicity effect up to dose $800 \mathrm{mg} / \mathrm{kg}$. The examined all parameters show it still in the normal range.

\section{CONCLUSION}

We treated albino rats with an ethanol extract of F. rukam stem bark to assess its toxicity. At each dose tested, blood biochemistry (SGOT, SPGT, and creatinine), and blood hematology (hemoglobin, erythrocytes, leukocytes, and hematocrit) were within an acceptable normal range. A significant difference was found between the control and treatment group that received doses at $800 \mathrm{mg} / \mathrm{kg} \mathrm{BW}$. However, the levels of the parameters evaluated were still within the normal range and therefore the extract has no toxic effect. Thus, it can be said that this extract can be continuously consecutive consumed for long term.

\section{ACKNOWLEDGMENTS}

We gratefully acknowledge the Ministry of Research Technology and Higher Education Indonesia for funding this research as part of the scheme for basic research superior higher education institutions 2020. We would also like to thank Universitas Sriwijaya for its facilities. The authors would also like to thank Dr. Addy Rachmad for his assistance in the preparation of this manuscript.

\section{AUTHOR CONTRIBUTIONS}

All authors made substantial contributions to conception and design, acquisition of data, or analysis and interpretation of data; took part in drafting the article or revising it critically for important intellectual 
content; agreed to submit to the current journal; gave final approval of the version to be published; and agree to be accountable for all aspects of the work. All the authors are eligible to be an author as per the international committee of medical journal editors (ICMJE) requirements/guidelines.

\section{CONFLICTS OF INTEREST}

The authors report no financial or any other conflicts of interest in this work.

\section{ETHICAL APPROVALS}

The experimental protocol was approved by the Ethics Commission of Sriwijaya University (No. 072/keprsmhfkunsri/2020).

\section{PUBLISHER'S NOTE}

This journal remains neutral with regard to jurisdictional claims in published institutional affiliation.

\section{REFERENCES}

1. Ekor M. The growing use of herbal medicines: Issues relating to adverse reactions and challenges in monitoring safety. Front Pharmacol 2014;4:177.

2. Bnouham M, Ziyyat A, Mostafa E, Legssyer A. Toxic effects of some medicinal plants used in Moroccan traditional medicine. Moroccan Biol J 2006;2:21-30.

3. Yustian I, Muharni M, Zulaicha S, Arbi M. Special research on the exploration of ethnomedicine and local community medicinal plants in Indonesia (Ethnic Musi II). Palembang: Ministry of Health Republic of Indonesia; 2012.

4. Ragasa CY, Jo MA, Theresa JT, Maria CS, Irving D, Robert B, et al. Chemical constituents of Flacourtia rukam Zoli. \& Moritzi fruit. Int J Pharm Clin Res 2016;8:1625-8.

5. Muharni M, Elfita E, Heni Y, Julinar J, Yasrina Y, Miranti M. Chemical constituents from stem bark of Flacourtia rukam Zoll. \& Mor. and their antioxidant activities. Sains Malaysiana 2019;48:1899-906.

6. Muharni M, Julinar J, Heni Y, Fitrya F, Rima M. In vitro anticholesterol and antihypertensive activity of stem bark the Flacourtia Rukam. Abstracts Book ICONART 2020; $p 91$.

7. Alimuddin A, Murtini S, Faridah N, Nuryati S. Behavior, histopathology and physiological responses of rat fed diets containing growth hormone transgenic fish meal. Hayati J Biosci 2019;26:1-6.

8. Ping KY, Darah I, Chen Y, Sreeramanan S, Sasidharan S. Acute and subchronic toxicity study of Euphorbia hirta L. methanol extract in rats. Biomed Res Int 2013;2013:182064.

9. Wang Y, Wei B, Tian Y, Wang Z, Tian Y, Tan S, et al. Evaluation of the potential effect of transgenic rice expressing Cry1 $\mathrm{Ab}$ on the hematology and enzyme activity in organs of female Swiss rats. PLoS One 2013;8:e80424.

10. Mitruka BM, Rawnsley HM. Clinical Biochemical and Hematological Reference Values in Normal Experimental Animals. $2^{\text {nd }}$ ed. Chicago, USA: Year Book Medical Publishers Inc.; 1981. p. 3.

11. Fitrya F, Fithri NA, Muharni M. A subchronic toxicity test of ethanol extract from Tunjuk langit rhizome (Helminthostachys zeylanica) on albino rats, Rattus noverticus (Wistar strain). Asian J Pharm Clin Res 2017;10:270-3.

12. Gupta D, Bhardwaj S. Study of acute, subacute and chronic toxicity test. Int J Adv Res Pharm Biol Sci 2012;1:103-14.

13. Prado-Ochoa MG, Abrego-Reyes VH, Velázquez-Sánchez AM, Muñoz-Guzmán MA, Ramírez-Noguera $\mathrm{P}$, Angeles $\mathrm{E}$, et al. Subchronic toxicity study in rats of two new ethyl-carbamates with ixodicidal activity. Biomed Res Int 2014;2014:467105.

14. Giknis ML, Clifford CB. Clincal Laboratory Parameter for Crl:WI(Han) Rats. Wilmington: Charles River Laboratories; 2008. p. 14.

15. Adebayo AH, Zeng GZ, Zhang YM, Ji CJ, Akindahunsi AA, Tan NH. Toxicological evaluation of precocene II isolated from Ageratum conyzoides L. (Asteraceae) in Sprague Dawley rats. Afr J Biotechnol 2010;9:2938-44.

16. Kumar V, Makkar HP, Becker K. Detoxified Jatropha curcas kernel meal as a dietary protein source: Growth performance, nutrient utilization and digestive enzymes in common carp (Cyprinus carpio L.) fingerlings. Aquac Nutr 2011;17:313-26.

17. Preet S, Prakash S. Haematological profile in Rattus norvegicus during experimental cysticercosis. J Parasit Dis 2011;35:144-7.

18. Huber N, Marasco V, Painer J, Vetter SG, Göritz F, Kaczensky P, et al. Leukocyte coping capacity: An integrative parameter for wildlife welfare within conservation interventions. Front Vet Sci 2019;6:105.

19. Aboderin FI, Oyetoyo VO. Haematological studies of rats fed different doses of probiotic, Lactobacillus plantarum, isolated from fermenting corn slurry. Pak J Nutr 2006;5:102-5.

20. Hasimun P, Susilawati E, Riduan A. Antiobesity activity of katuk (Sauropus androgynous L. Merr) extract in obese mouse model. Pharm J Indones 2017;14:137.

\footnotetext{
How to cite this article:

Muharni M, Fitrya F, Saputra O, Yohandini H, Julinar J. A subchronic

toxicity test of Flacourtia rukam stem bark extract on the albino rat Rattus noverticus (Wistar strain). J App Biol Biotech. 2021;9(3):83-88.

DOI: $10.7324 / J A B B .2021 .9311$
} 